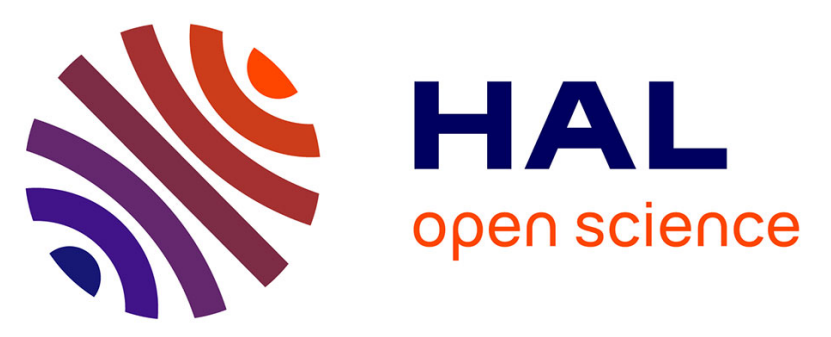

\title{
Erratum to: "Efficacy and safety of vaginally administered lyophilized Lactobacillus crispatus IP 174178 in the prevention of bacterial vaginosis recurrence" [J. Gynecol. Obstet. Hum. Reprod. 47 (2018) 81-7]
}

J.M. Bohbot, E. Darai, F. Bretelle, G. Brami, C. Daniel, J.M. Cardot

\section{To cite this version:}

J.M. Bohbot, E. Darai, F. Bretelle, G. Brami, C. Daniel, et al.. Erratum to: "Efficacy and safety of vaginally administered lyophilized Lactobacillus crispatus IP 174178 in the prevention of bacterial vaginosis recurrence" [J. Gynecol. Obstet. Hum. Reprod. 47 (2018) 81-7]. Journal of Gynecology Obstetrics and Human Reproduction, 2018, 47 (4), pp.177. 10.1016/j.jogoh.2018.03.005 . hal-02006511

\section{HAL Id: hal-02006511 \\ https://hal-amu.archives-ouvertes.fr/hal-02006511}

Submitted on 20 Mar 2019

HAL is a multi-disciplinary open access archive for the deposit and dissemination of scientific research documents, whether they are published or not. The documents may come from teaching and research institutions in France or abroad, or from public or private research centers.
L'archive ouverte pluridisciplinaire HAL, est destinée au dépôt et à la diffusion de documents scientifiques de niveau recherche, publiés ou non, émanant des établissements d'enseignement et de recherche français ou étrangers, des laboratoires publics ou privés. 


\title{
Erratum
}

Erratum to: "Efficacy and safety of vaginally administered lyophilized Lactobacillus crispatus IP 174178 in the prevention of bacterial vaginosis recurrence" [J. Gynecol. Obstet. Hum. Reprod. 47 (2018) 81-7]

\author{
J.M. Bohbot ${ }^{\text {a }}$, E. Daraï ${ }^{\text {b }}$, F. Bretelle ${ }^{\text {c }}$, G. Brami ${ }^{\text {d,* }}$, C. Daniel ${ }^{\text {d }}$, J.M. Cardot $^{\mathrm{e}}$ \\ ${ }^{a}$ Institut Alfred-Fournier, 75014 Paris, France \\ ${ }^{\mathrm{b}}$ Service de gynécologie-obstétrique et médecine de la reproduction, hôpital Tenon, université Pierre-et-Marie-Curie, UMRS 938, AP-HP, 75020 Paris, France \\ ${ }^{\mathrm{c}}$ Department of gynaecology and obstetrics, gynépole, AMU, Aix-Marseille université, UM63, CNRS 7278, IRD 198, Inserm 1095, Assistance publique- \\ Hôpitaux de Marseille, 13005 Marseille, France \\ d Laboratoires IPRAD PHARMA, 174, quai de Jemmapes, 75010 Paris, France \\ e Université Clermont-Auvergne, UMR MEDIS, CHU de Clermont-Ferrand, 63000 Clermont-Ferrand, France
}

In the original version of the article, two figures were wrong.

Page 82, the paragraph Materials and methods should be:

After completing the treatment with metronidazole, patients with a Nugent score $>7$ at visit 1 and clinically cured at visit 2 (i.e., no Amsel criteria) were randomised to receive vaginal capsules of a placebo or of L. crispatus IP 174178 ( $10^{9} \mathrm{CFU}$ per gram).

Page 85, the paragraph Discussion should be:

Our results also confirm the in vitro studies by Mc Lean N. W. and Rosenstein I.J. [26], which showed that L. crispatus 55730 inhibited pathogenic vaginal bacteria, and by Atassi et al. [27] showing that L. crispatus $\left(10^{8} \mathrm{CFU} / \mathrm{mL}\right)$ inhibited G. vaginalis or Prevotella bivia in co-culture for 4 hours.

This correction has been made to the online version as of "24 march 2018".

Our apologies to the authors and our readers for these mistakes.

DOI of original article: https://doi.org/10.1016/j.jogoh.2017.11.005

* Corresponding author.

E-mail address: g.brami@iprad-labo.com (G. Brami). 